Research Article

\title{
Efficiency of Learning Software 'Sinding Pimato' Towards Reading Achievement of Kadazandusun Language for Year One Pupils
}

\author{
Marbella Binti Justine ${ }^{1}$, Norjietta @ Julita Binti Taisin², Rosliah Kiting3 \\ Universiti Pendidikan Sultan Idris
}

\begin{abstract}
Reading skill is an important skill in Kadazandusun language to enable pupils to follow and master the teaching and learning in the classroom. However, the findings from previous studies show that most pupils in primary schools have yet to master the basic skills of reading in the pronunciation aspect. Therefore, this study has to be carried out to study the effectiveness of 'Sinding Pimato' software application on the reading achievement of the Year One pupils. This study is a quasi-experimental study. The quantitative approach is used together with pre and post-test instruments. A total of 30 Year One pupils in a school at Tambunan District have become the sample for this study. The sample of the study was divided into two groups, namely the experimental group taught using 'Sinding Pimato' software and the control group taught by Chalk and Talk method. The findings show that there is a significant difference in the achievement of reading between the experimental group and the control group. The findings of this study show that the application of 'Sinding Pimato' learning software is effective in helping to improve the achievement of reading for the Year One pupils. In conclusion, the 'Sinding Pimato' software has an effective effect as a learning tool for Kadazandusun Language. The implication of the study shows that the 'Sinding Pimato' software is useful to improve the quality of teaching and learning Kadazandusun language curriculum.
\end{abstract}

Keywords: Reading skill, pronunciation aspect, Year One pupils, 'Sinding Pimato’’ software.

\section{Introduction}

The Kadazandusun language is the identity of the Kadazandusun community. In this regard, the Kadazandusun Language curriculum implemented in primary schools in Sabah is a noble effort of the Ministry of Education of Malaysia (KPM) to uphold the Kadazandusun language in order that the language will not extinct over the years and be transformed into a legacy to Kadazandusun's children. This is in line with the opinion by Rosliah (2012) that the development of this language is a way to continue the heritage of the nation, especially among the younger generations of Kadazandusun. Reading is one of the most important aspects. According to Yahya (2005), reading is intended to ensure the message contained in the text is understandable. Abdul Rasid Jamian (2012) also said that if the pupils are mastering the reading skills, they can easily pronounce each word accurately and correctly, understand the meaning of the words and measure the ability of the pronunciation achievement and achieving the goal of reading. Therefore, in Kadazandusun Language subjects, reading skills should be prioritized so that the students do not have any problems in reading that would cause them to have no interest in the subject. This is in line with the opinion of Minah (2015) that pupils who are weak and have no interest in Kadazandusun Language due to the incompetence problem of mastering basic reading skills. Based on the problem in reading, the researcher has conducted a study on the use of 'Sinding Pimato' software developed by the researcher to improve the reading achievement of pupils in pronunciation aspect. The 'Sinding Pimato' learning software is the innovation of teaching methods by Jolly Phonic (Chris
Jolly, 1992) used in English teaching. The application of 'Sinding Pimato' learning software application is using a phonemic and edutainment. The phonemic approach is using sound synthesis for learning by showing the sound of each letter, then combining it with other letters until the sound of the whole word is heard.

This study is in line with the development of Information and Communication Technology (ICT) which is integrated into Kadazandusun language teaching and learning. The 'Sinding Pimato' software is an interactive ICT based learning software with the application of audio, graphics, text, animation and video multimedia elements as a teaching aid in the classroom. The use of this software will enable fun learning environment, fulfilling the $21 \mathrm{st}$ Century Education components, more effective, attracting students, productive and more meaningful by combining learning multimedia in Kadazandusun language. This is in accordance with the opinion of Abdul Rashid Jamian (2012) that multimedia learning can be a stimulus and attraction to pupils because multimedia is capable of providing information more quickly and accurately and fun than using Chalk and Talk teaching methods. Faridah (2013) expresses the concept of teaching 'Chalk and Talk' as the teacher only serves as the main instructor in front of the class and the student only listen to the information that the techer wishes to convey. This method is less relevant to teaching and learning of Kadazandusun Language. It is in line with the opinion by Caine \& Caine (1994) that the Chalk and Talk approach is less relevant for today's needs. Hence, through this integration, pupils who will use learning materials 'Sinding Pimato' will 
have more freedom and more flexible in searching and enhancing the reading knowledge with the proper pronunciation. This is because in order to improve reading achievement, teachers need to use ICT to develop studentcentered teaching and learning and more systematic (Abdul Rashid Jamian, 2012).

\section{Study Purpose}

This study aims to examine the effectiveness of using 'Sinding Pimato' learning software in the achievement of reading skills in terms of pronunciation for Year One pupils.

\section{Study Objectives}

1. Identify the percentage of pronunciation achievement before and after the students are exposed to the teaching and learning of 'Sinding Pimato'.

2. Explain the difference in mean score and the standard deviation of the pronunciation achievement before and after the pupils are exposed to 'Sinding Pimato'.

\section{Study Questions}

Specifically, this research aims to answer the following questions:

1. What is the percentage of the achievement before and after the pupils are exposed to 'Sinding Pimato'?

2. Is there a difference in mean and standard deviation of achievement before and after the pupils are exposed to 'Sinding Pimato'?

\section{Study of Conceptual Concept}

This study focuses on the use of ASSURE Model and Cognitive Theory to explore the effectiveness of 'Sinding Pimato' in the achievement of reading in Kadazandusun language. The following is a framework for the research. The conceptual framework of this study is based on the results of the conceptual framework by Ahmad Zamzuri Mohamad Ali (2018).

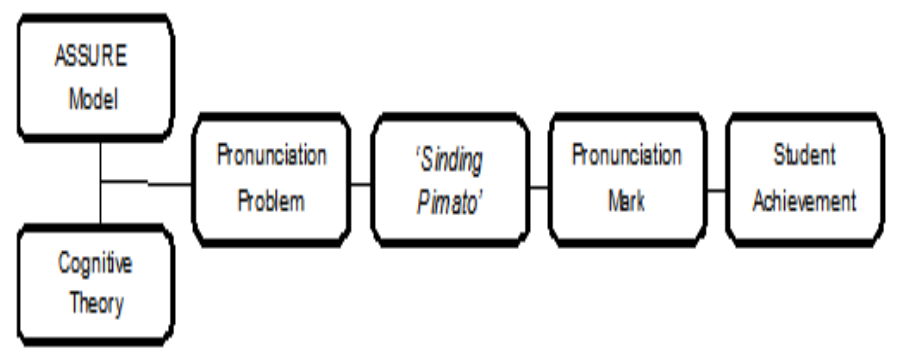

Figure 5.1 Conceptual Framework Research (Adaptation of conceptual framework research by Ahmad Zamzuri Mohamad Ali, 2018).

\section{Literature Study}

Sinclair and Papamdrapoula (1984), stated that children at the age of seven need to master the phonemes to enable them to read smoothly. Hakkinen (2006), has studied that the use of learning software as a teaching aid in language subjects can bring a positive impact on learning outcomes. Suraya Tarasat (2014), also states that children at six years old (preschool) can easily master the basics of reading when the teachers use appropriate learning software. The findings of Vespanathan (2014), proved that reading learning software can improve better pronunciation. In Kadazandusun Language subject, Norjietta (2017), also stated that teachers need to apply ICT to create more effective teaching and learning. In conclusion, Ahmad Zamzuri (2018), gave the opinion that ICT's integration into language has the ability to improve reading skills compared to Chalk and Talk teaching. The breakdown from the previous study revealed that the basic mastery of reading skills should be based on ICT but there is no software package specifically in Kadazandusun language. Thus, this study needs to be carried out.

\section{Research Methodology}

\subsection{Research Design}

In the context of this study, researchers have chosen a quasiexperimental study. The type of quasi-experimental design used in this research is the pre-test design and post-test group experiments and control groups. This is in line with the purpose of this study which is to evaluate the effectiveness of the use of 'Sinding Pimato' learning software to improve the achievement of Year One pupils in t reading. 'Sinding Pimato' is a learning material for Kadazandusun Language. Additionally, researchers also make comparisons between traditional teaching methods, namely Chalk and Talk methods with 'Sinding Pimato' learning software assistance. Thus, this study examines the effect of two basic methods of teaching basic reading skills on the reading achievement of two groups of Year One pupils. Experimental groups were exposed to teaching based on 'Sinding Pimato' learning software while the control group was exposed to Chalk and Talk teaching. Below is a design diagram for this study.

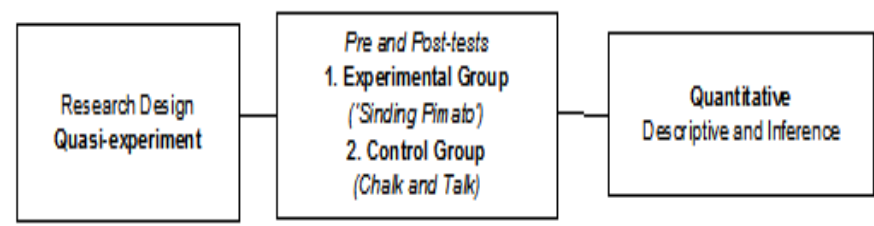

Figure 7.1 Design of Research Effectiveness on 'Sinding Pimato' Towards the Achievement of Kadazandusun Pronunciation for Year One Pupil.

\subsection{Research Sample}

According to Azizi Yahaya (2017), the use of sample in a study is important to ensure the research is easier and effective, meticulous and careful especially during the data collection process. Hence, this research is conducted at a national primary school located in Tambunan district, Sabah. In this research, the population consists of pupils who undergo formal Kadazandusun Language curriculum and have the same community background as Dusun. The sample of this study involved 30 Year One pupils in the school. Pupils are then divided into two groups, namely the experimental group and the control group. A total of 15 students in the experimental group consisted of seven female pupils and eight male pupils. Meanwhile, the control group is represented by 15 students which consist of 10 female and five male pupils.

\subsection{Research Instrument}

The following is a study instrument applied in this research study; 


\section{Daily Teaching Plan (DTP)}

There are two set of daily lesson plans provided by the researcher to implement in teaching reading in this study, namely a lesson plan for an experimental group created based on the ASSURE Teaching Model with the application of teaching using 'Sinding Pimato' software, and lesson plan for the control group which applies Chalk and Talk teaching. To ensure the validity of this lesson plan, the researcher referred to the Kadazandusun Language Head and also the supervisor.

\section{2. 'Sinding Pimato' Learning Software}

This software is built using Android Studio 3.0 for smartphones and Visual Studio software applications for Window software applications. This software has the same storyboards and focuses on four basic reading skills, namely recognizing the sounds of letters, pronuncing open and closed syllables, combining open and closed syllable sounds and reading short sentences. The selected Vowel letters are a, i, o, u and consonant letters are $\mathrm{b}, \mathrm{d}, \mathrm{f}, \mathrm{g}, \mathrm{j}, \mathrm{m}, \mathrm{n}$ and $\mathrm{y}$. To ensure the validity of the content and the software, the researcher referred to the supervisor who is the lecturer of the Department of Information Technology and Communication of Sultan Idris Education University and the Head of Kadazandusun Language of Kiawayan Primary School, Tambunan.

\section{Test Set}

There are two sets of reading tests, i.e. pre test and post-test. The details in the pre and post test are the same. This test contains 10 constructs covering 4 sections, namely sound test, test combining consonant and vowel sounds, test combining two open letters sound and reading short sentences. The overall score of this test is 50 marks. Each question has a value of five marks. To ensure the validity of the test content, the researcher also referred to the supervisory lecturer and Head of Kadazandusun Language. The overall test constructs can be seen in Table 1 below.

Diagram 7.1 Distribution of overall test construct

\begin{tabular}{llc}
\hline Construct & Skill & Mark \\
\hline 1 & $\begin{array}{l}\text { Ability to pronounce vowel and } \\
\text { consonant. }\end{array}$ & 5 \\
\hline 2 & Ability to pronounce open syllable. & 5 \\
\hline 3 & Ability to pronounce open syllable word. & 5 \\
\hline 4 & Ability to pronounce closed syllable. & 5 \\
\hline 5 & $\begin{array}{l}\text { Ability to pronounce words containing } \\
\text { closed syllable. }\end{array}$ & 5 \\
\hline 6 & $\begin{array}{l}\text { Ability to pronounce words containing } \\
\text { syllable closed 'ng'. }\end{array}$ & 5 \\
\hline 7 & $\begin{array}{l}\text { Ability to pronounce words containing } \\
\text { combined vocals. }\end{array}$ & 5 \\
\hline 8 & $\begin{array}{l}\text { Ability to pronounce words containing } \\
\text { combined consonant. }\end{array}$ & 5 \\
\hline 9 & $\begin{array}{l}\text { Ability to pronounce the words with } \\
\text { prefix and suffix. }\end{array}$ \\
\hline 10 & $\begin{array}{l}\text { Ability to pronounce and read simple } \\
\text { sentences. }\end{array}$ & 5 \\
\hline
\end{tabular}

\subsection{Data Analysis}

All the data obtained from reading tests are quantitative. These data are collected and analyzed using Statistical Package for the Social Science (SPSS). To see the distribution of reading achievement scores of experimental group and control groups in pre and post-test, percentage descriptive analysis is used. The independent sample $t$ test inference statistics and paired sample $t$ test are used to compare the mean levels of student achievement in pre and post-tests in pronunciation aspect for both experimental and control groups. The degree of significance for all inference tests is 0.05 .

\section{Finding and Discussion}

The findings of this study were answered by answering both questions and discussed as the following: 8.1 Question 1: How many percent of the achievements before and after the students are exposed to 'Sinding Pimato'?

\subsubsection{Experimental Group}

Based on the finding, percentage achievement for the experimental group and the control group in pre and post-tests, the researcher found that the percentage of pronunciation achievement for the experimental group has increased significantly in post-test after using Sinding Pimato software. The following is a graph of achievement percentage in reading marks for experimental groups in pre-test and post-test.

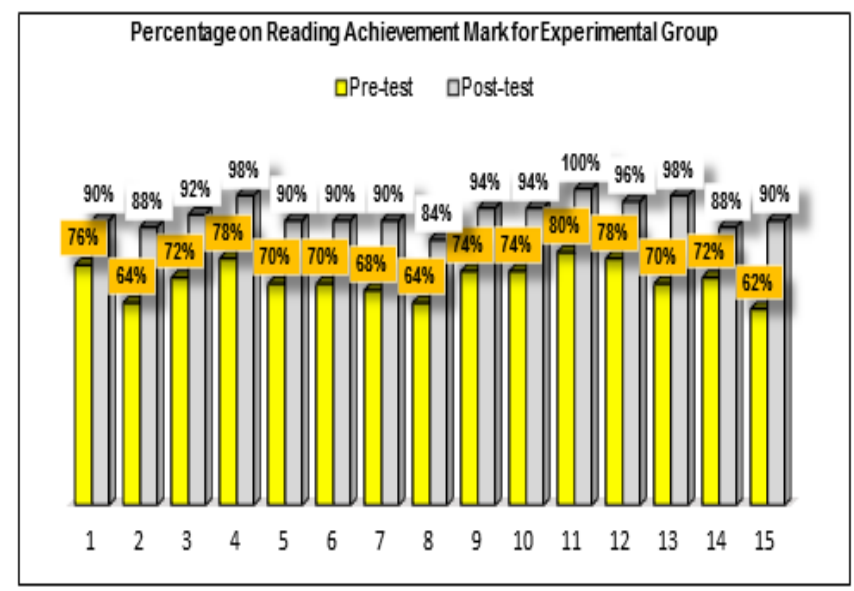

Figure 7.1 Percentage on improvement of pre and post-test achievement marks for experimental groups.

From diagram 7.1, it is evident that all respondents in the experimental group have achieved excellent level of achievement by scoring $80 \%$ to $100 \%$ with an increase of $14 \%$ to $28 \%$ after learning using 'Sinding Pimato' software. The increase in percentage marks shows that the learning of phonics with 'Sinding Pimato' software is effective to improve the achievement of pronunciation for experimental groups. The findings of this study support the opinion by Yahya Othman (2012) that the method of phonics is a method of teaching basic reading that are appropriate to be applied at the children's level. Thus, the phonics method is best suited for them to master the basic pronunciation. As showed in diagram 7.1, the percentage of preliminary achievement in pre-test is low which is about $60 \%$ to $78 \%$. This shows that the students of the experimental group do not master the reading basic, namely the 

Minority-Underserved Communities in the State of Mississippi?

pronunciation effectively. Thus, researchers use this 'Sinding Pimato' software to help students of the experimental group to increase the pronunciation percentage easily through the phonics method. The increase in reading achievement is also influenced by ICT integration in teaching and learning of Kadazandusun Language. In conclusion, the findings show that teaching using 'Sinding Pimato' learning software is very appropriate and effective to improve student's pronunciation. Hence, the findings support the opinion by Norjietta (2017) that the use of interactive multimedia in Kadazandusun language is able to improve the students' achievement in reading comprehensively.

\subsubsection{Control Group}

For the control group, the percentage increase in pre-test is not prominent after the teaching and learning method of Chalk and Talk. The following is a graph of reading achievement percentage for control groups in pre-test and post-test.

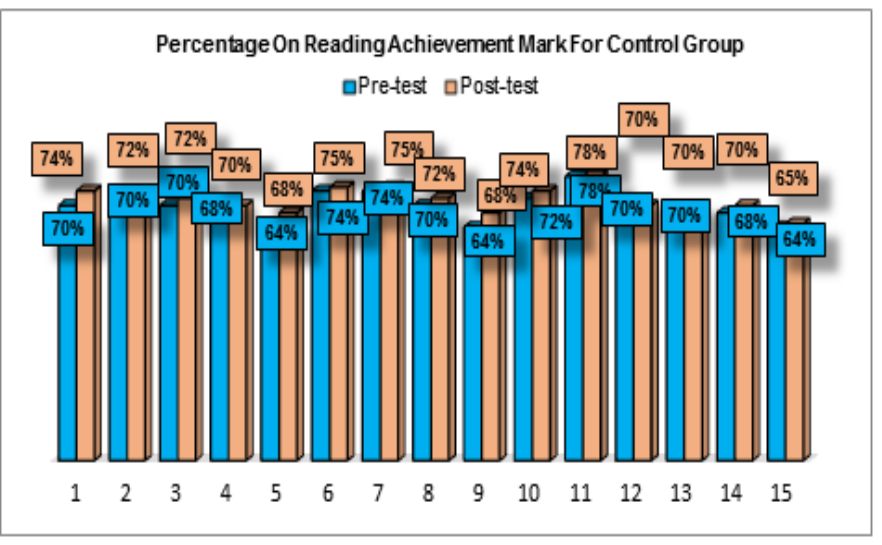

Figure 7.2 Percentage on improvement of pre and post-test achievement mark for control group.

Based on diagram 7.2, the percentage of improvement in posttest achievement marks showed a low increase that is about $0 \%$ to $4 \%$ with the highest score of $78 \%$. This shows that the achievement of remote control groups is lagging with the achievement marks for experimental groups. This shows that the Chalk and Talk teaching method is ineffective to increase the reading level of control group. Hence, the teaching method of Chalk and Talk which is often used by Kadazandusun Language teachers in this school is ineffective in improving the pronunciation of pupils. The findings support the opinion of Caine \& Caine (1994) that Chalk and Talk teaching is less relevant to today's needs. This means that the percentage of the achievement of the pronunciation aspect after the control group of pupils undergo a reading session using Chalk and Talk does not show much improvement. In conclusion, the use of multimedia as a teaching aid is more effective than Chalk and Talk teaching methods. This finding is consistent with the opinion of Bennet (1996) that ICT integration in teaching and learning are more effective than teaching by using Chalk and Talk method.

8.2 Question 2: Is there a difference in mean and achievement on standard deviation of the pronunciation aspect before and after the student is exposed to 'Sinding Pimato'?
Before the teaching session began, the two groups of experimental groups and control groups were given pre-test and post-reading pronunciation tests in Kadazandusun language. The data were then analyzed to determine the mean score and the standard deviation of achievement for both groups. The data were then analyzed using the t-test (t-test) to see the differences in student achievement for the teaching method of 'Sinding Pimato' and Chalk and Talk teaching methods for the control group used in Kadazandusun Language learning. The findings of measurements of the mean score difference and the standard deviation of both groups can be seen in Table 8.1 below,

Table 8.1 $\mathrm{T}$ test analysis of overall achievement in pronunciation of Kadazandusun Language between experimental group and control group before and after the analysis.

\begin{tabular}{cccc}
\hline $\begin{array}{c}\text { Mean score } \\
\text { difference } \\
\text { between }\end{array}$ & $\begin{array}{c}\text { T-count } \\
\text { value }\end{array}$ & $\begin{array}{c}\text { Degree of } \\
\text { Freedom } \\
\text { two groups }\end{array}$ & $\begin{array}{c}\text { Significant } \\
\text { Value }\end{array}$ \\
\hline-.56333 & -5.785 & 29 & $\mathrm{P}<.05$ \\
\hline
\end{tabular}

Table 7.1 shows the difference of pronunciation achievement between the experimental group and the control group. The statistic results of $\mathrm{t}$ test showed a significant difference $(\mathrm{t}=$ $5.785, \mathrm{p}>.001)$. This difference shows that there is an increase in the reading achievement of the experimental group after using 'Sinding Pimato' software compared to the control group. Therefore, this t test analysis shows that the mean score and the standard deviation obtained by the experimental group is different before and after being exposed to 'Sinding Pimato'. Thus, the high differences in the achievement of the students' pronunciation of the experimental group show that the learning software 'Sinding Pimato' is effective in improving reading Kadazandusun language. The findings of this study support the opinion by Beechler \& Williams (2012), that there is an increase in the achievement of word pronunciation skills in language teaching when the teacher is using computer-assisted for teaching and learning. As a result, the use of 'Sinding Pimato' software is effective in stimulating language cognition and enhancing the achievement of reading in the experimental group. In conclusion, to stimulate the student's mind towards language teaching and learning, teachers should use multimedia-based teaching aids. This finding also agrees with the opinion by Norjietta (2017), that Kadazandusun Language teachers should use interactive multimedia to create effective teaching and learning.

\section{Research Implication and Conclusion}

This study was conducted with the aim of studying the effect of using 'Sinding Pimato' learning software in the teaching and learning of Kadazandusun Language for the Year One pupils. Based on the findings of the study, the use of 'Sinding Pimato' software is more effective in helping to improve the student's pronunciation compared to teaching in Chalk and Talk. The implications of the study have shown that the 'Sinding Pimato' software is useful to improve the quality of teaching and 
learning Kadazandusun Language curriculum.

\section{Reference}

1. Abdul Rasid Jamian (2012). Multimedia Interaktif Mempertingkatkan Pembelajaran Kemahiran Membaca Murid-Murid Probim, Jurnal Pendidikan Bahasa Melayu - Jpbm (Malay Language Education Journal - Mylej) Vol, 2, Hlm. 46-53

2. Ahmad Zamzuri Mohammad Ali (2018). Multimedia Dan Perisian Pendidikan. Panduan Praktikal Reka Bentuk Dan Penyelidikan. Penerbitan Univerisiti Pendidikan Sultan Idris.

3. Azizi Yahaya, Peter Voo, Ismail Maakip dan Mohd Dahlan A. Malek (2017). Kaedah Penyelidikan Dalam Pendidikan. Penerbitan Universiti Pendidikan Sultan Idris.

4. Bennett \&Frederick (1999). Computers As Tutors: Solving The Crisis In Education. Faben Inc. Httpi/Www.Cns.Com: 80/ Fabenl/Fullbook. Html

5. Faridah Yunus (2013). Teknik Multisensori Dalam Pengajaran Dan Pembelajaran Literasi Huruf KanakKanak Prasekolah. Universiti Kebangsaan Malaysia.

6. Hakkinen, P. (2006). Learning Together: Understanding The Process Of Computer-Based Collaborative Learning. Elsevier Science Ltd.

7. Julita@Norjietta Binti Taisin, (2017). Keberkesanan Kaedah Pengajaran dan Pembelajaran Bahasa Kadazandusun dalam Kalangan Guru BahasaKadazandusun Sekolah Rendah di Daerah Ranau Sabah: Tinjauan Awal. Universiti Pendidikan Sultan Idris.

8. Minah Sintian (2015). Kopointutunan Sintaksis Boros Kadazandusun ( Pengenalan Sintaksis Bahasa Kadazandusun ). Universiti Pendidikan Sultan Idris.

9. Rosliah Kiting (2012). Pengenalan Morfologi Bahasa Kadazandusun. Dalam Abdul Hamid Mahmood, Siti Saniah Abu Bakad Dan Sanat Md. Nasir (Editor). Memartabatkan Bahasa Melayu Pengajian Bahasa. Tanjong Malim: Universiti Pendidikan Sultan Idris., Hlm. 225-239.

10. Suraya Tarasat. (2014). Kesan Penggunaan Perisian Asas Membaca Terhadap Pencapaian Membaca Murid Peringkat Prasekolah. Procedia - Social And Behavioral Sciences. Vol. 134. 399-407.

11. Vespanathan Supramaniyam. (2015). Penggunaan Teknologi Maklumat Dan Komunikasi (TMK) Dalam Kalangan Guru-Guru Mata Pelajaran Kemahiran Hidup Di Sekolah Rendah Luar Bandar Negeri Johor. Retrieved From Http://Eprints.Uthm.Edu.My/8014/1/Vespanathan_Supram aniyam.Pdf

12. Yahya Othman (2005). Trend Dalam Pengajaran Bahasa Melayu. Pahang Darul Makmur: PTS Professional Printing Sdn. Bhd.

13. Yahya Othman\& Roselan Baki (2015). Aplikasi Komputer Dalam Pengajaran Bahasa : Penguasaan Guru Dan Kekangan Dalam Pelaksanaan. 1st International Malaysian Educational Technology Convention. 